\begin{tabular}{ll}
\hline \hline MINING AND METALLURGY INSTITUTE BOR & ISSN: 2334-8836 (Štampano izdanje) \\
UDK: 622 & ISSN: 2406-1395 (Online) \\
\hline \hline
\end{tabular}

UDK: $622.012: 65 \cdot 012.323(045)=111$

doi: $10.5937 / \mathrm{mmeb} 1802109 \mathrm{R}$

Vladimir Radovanovic *

\title{
HUMAN POTENTIAL DEVELOPMENT IN THE MINING COMPANIES
}

\begin{abstract}
The new century has inaugurated a number of changes that can be attributed to the process of globalization of the world economy. Globalization with its influence brings a number of technological, economic, educational, social, and political and many other changes that have transformed the world economy, and have a significant impact on the business environment. The process of globalization brings a completely new concept of intellectual capital, with a clear and strong focus on the human potential, as its key component, pointing to its role and place in economic life. This paper presents the most important component of intellectual capital, which is the human potential. This is because of the role and significance of knowledge that becomes the central resource and bases of intellectual capital, and is the carrier of development and overall creativity. The knowledge and its application become the key form of material, spiritual, and every other social wealth. Rightfully, today's economy is called the "knowledge economy" because the creativity is based on the knowledge and innovation. Depending on the environment, defined by the economic horizon, the companies are referred to a strategic approach to the business development on the basis of strategy of developing their human potential, so these two strategies become compatible and inseparable. For the strategy of human resources development, as the most important segment of the social strategy, it is necessary to improve and promote the market for education and professional development. Today, instead of the global objective of education to provide the individual with a lifelong knowledge, in the foreground, the objective of education is to teach an individual to acquire the knowledge throughout his/her life, i.e. permanently educate and develop. The aim of this paper is to point out the importance, role and place of intellectual capital in companies with an emphasis on its progressive and constant change, i.e., development. By an empirical research, the role and development of knowledge will be proven in the Serbian mining companies which are part of the global economy.
\end{abstract}

Keywords: human resources, intellectual capital, knowledge, permanent education, mining company, mining development in Serbia

\section{INTRODUCTION}

The most developed countries of the world have highlighted the human potential as the newest and most important competitive factors of economic success. The fast economic development requires a new functional knowledge, and hence education and training have a key role and importance for further development. In order to be a part of the business world, to create it, we should

continue to develop economically, we need to increase our arsenal of knowledge and develop the human potential of our mining companies. The European experiences tell us that during the human lifetime, the technology changes up to 10 times, and with this an employee changes own profession at least 5 to 6 times, which is not the case in the mining companies because of the very na

\footnotetext{
* Faculty of Technical Science Cacak
} 
ture of those jobs. This tells us that once learned, it can only serve as a start, where it quickly becomes insufficient. The transition economy in which the Serbian economy still exists has a new dimension in which there is a possibility that a large number of employees will lose their jobs for which they have been educated, and are forced to accept another job for which there is a need for society. Such conditions, as well as the ever-faster development of science and technology, as well as the changing conditions in the market and the environment, imply a growing need for permanent development of employees. That is why the all educational institutions and centers are assigned to find out how to help the employee in gaining a new and innovating the existing knowledge and skills. The answer lies in the fact that today it is necessary for the entire educational and scientific system to be oriented towards the production and diffusion of intensive knowledge, as well as the flexible disposal and use the existing knowledge and its continuous improvement. The classic role of companies is changing. Today, in addition to their work role, the companies have an educational role as well. Such education can give good effects in development the human resources. Today, there is a well-developed informal form of education serving the development of human resources in the companies. These are various forms of training and education that can be realized in addition to the classical methods of realization through the Internet, E-education, M-education, and other forms of distance learning, which will be discussed in this paper.

\section{HUMAN POTENTIALS - FACTOR OF COMPETITIVE ADVANTAGE}

Human potential is the only initiator of intellectual capital in the company. It relates to the accumulated value of investment in education, skills and future of all employees and their ability to transform their knowledge, skills and experience into the active creation of added value for the mining company.

Intellectual capital is a thermonuclear competitive weapon of the present, [1] telling us a lot and reflecting the power of human potential and their functional knowledge. In order to maximally and efficiently use this power of intellectual capital for the sake of further development and prosperity, it is necessary to fully understand its essence, role and way in which it develops. Companies are biology-sociologicaleconomic organisms, which, in addition to the material basis, consist of people who, with their knowledge, abilities and skills, give meaning, purpose and useful value to all material elements as well as the mining company itself. Human being is confirmed as the most important factor of the company and its basic factor, the initiator and creator of new values, as well as the carrier and creator of all the changes that occur in an environment and company itself. Human is the one who gives the essence of life to the company and gives meaning and goals to the overall creative activities that occur and are carried out.

Human potential - a human being with knowledge, abilities, skills, creativity, motivation, attitudes, and working energy is primary in the development of the economy. A man represents the motor power, social and economic changes and is an inventive and creative factor in the process of creativity and management of companies regardless of their nature of work. Human potential is all that people know, for what are capable and skilled, experience that help them to anticipate the outcome and possible mistakes during work and management. Human potential is a part of the intellectual capital which leaves the company after the end of working hours. Today, in a developed economic world, the human potential and human capitals are explained as the wealth of a country, a region, a region. It is at the same time a country's competitiveness and competence in the international market, not just in goods 
and services, but also the intellectual capital, knowledge and skills. Therefore, instead of a business based on formerly tangible assets, the companies must develop a sense of creating, transferring, integrating protection and rational use of their intangible intellectual property, or the most valuable form of capital they own. Due to the nature of work, the mining companies have to manage the knowledge in a proper way if they want to use it maximally.

Everything defined as resources or capital has to be managed in the way to use it efficiently and rationally. Resources, whether they are in natural, financial, energy, information, are basic condition for the proper performance of business and only human resource (potential, capital) has no alternative and has the ability to give meaning, purpose and use value to all resources. It is the only rational resource from which everything begins and on which each activity is based. Human resources, in order to be efficient, should also be managed, which is the primary task of human resources management. Human resources management is a part of the organization's science and it deals with the management of human work and their development.

\section{KNOWLEDGE-BASED ECONOMY}

An economy, based on intellectual capital - knowledge is a modern economy and includes the value of total produced and realized goods and services created on the basis of applied knowledge. It is emphasized that the today's world has entered a new era a period of knowledge and innovation. The basic infrastructural elements for prosperity in the knowledge economy are: knowledge as a source of economic development and innovation-as the most valuable source of creating new values and making changes. The age of knowledge sets the foundation for a new economic order and the chance of creating a new future, which is increasingly reliant on the value of human potential.
A new economic era is defined by many scientists, one of which is Peter Drucker, who points out that in the knowledge economy the natural resources and work are no longer the basic economic resources, but it is the intellectual capital that is defined as "knowledge that flows through technology and is found in humans" [2]

It follows from this that the knowledge is a priority factor of competitiveness. In the global business in the knowledge economy, competitiveness becomes tied to the individual economic entities, not to the national economies. Globalization as a universal process permeates all aspects of society, it breaks borders and establishes new connections and relationships creating conditions for faster and more efficient exchange of people, capital, goods, services, money, information and knowledge. Globalization of knowledge can be understood as the growth, development and knowledge exchange between different economic entities on a global basis.

In the knowledge economy, knowledge takes on some specifics and becomes the focus of interest in economic science and practice. Business in the knowledge economy is characterized by large and rapid changes at all levels and in all sectors and branches, business entities become more and more quality creators (new products, services, response to increased demands of consumers-markets), business has an international character, a new forms of cooperation between business systems, competition becomes more sophisticated and takes on new forms, the market is becoming more and more prominent, new demands of competitiveness are emerging.

The knowledge economy as a whole represents a transformed industrial economy where employees in the industrial economy are treated as a cost generator. In the knowledge economy, they are considered as generators of income and wealth and constitute the most valuable economic capital. The power of management in the 
industrial economy depends on the levels in the organizational hierarchy, but in the knowledge economy, the power of management depends on the level of knowledge it has at its disposal, i.e. of his competence.

The basic form of profit in the industrial economy was "tangible" - money, in the new economy the profit becomes "intangible", "invisible" - learning, new ideas, new qualities, standards, new customers and customers. The bottlenecks were money and skill which became time and knowledge in modern economy. The era of knowledge brings completely the new views on the world of economics, and inaugurates a completely new management. A man with his knowledge, abilities, habits, skills, creativity, motivation and energy is the most important factor in all human creativity and the bearer of the overall economic development at the present time. [3]

The economy of modern times and economic development are in a rapid rise and very complex and turbulent environment. In analyzing their competitive factors, the prevailing assumption is that a man with own values and position is not only a structure, but a basis from which everything starts and depends on . Changing the role and way of functioning of today's mining companies, as the subjects of industrial economy, is conditioned by a radical change in the role and importance of employees in them. Today, it is necessary to create the new, modern and high quality human resources, which can ensure the effective realization of business and development policy goals in conditions of the great economic uncertainty, rapid technological changes, dynamic transformation and change of the ownership relations.

The combination of labor and education, as well as their compatibility, has become an inevitable need of a modern and future businessman. The demand for developed and professional human potentials is changing faster than the human potential itself, hence there is a necessity of building a new human resource development strategy everywhere where they are present. The human resources development strategy is based on the "work and education", i.e. education in companies, which is a process of improvement leading to development and better quality of human potential [4]

Training programs should increase the flexibility of work and successfully overcome the rapid changes in any segment of mining companies, as well as to meet the legally prescribed requirements. The quality of human resources affects: behavior of people, change of working atmosphere, improvement of motivation for work, improvement of organizational culture, as well as change of working mentality and organizational behavior in a business system based on the ethical principles.

On the development and quality of employees, the US economist Peters T. said the following [5]

- Human capital should be invested as much as in the equipment,

- We train people from the first day and allow them to further improve whenever necessary,

- Comprehensive training includes the technical problem solving, so that people can contribute to the quality improvement,

- We organize training for people who transfer to the managers and continue to train them whenever they are transferred to a higher office,

- We use training as an incentive and strategic impulse,

- We insist that complete training is directed at people from the base, all programs should be based on the information from people from the base.

Training is progressing from the internal to dynamic; from a routine to a creative environment; from the "industry" of hierarchy, control and limiting compulsion to the "industry" of knowledge, cooperation, and intelligent choice of options. This approach to the professional and professional education and development of employees not only 
provides the high-level human potential, but also brings one message to every employee that is extremely important for their company. The new philosophy of development and business inevitably imposes an increasingly new attitude, it is necessary to understand how the

\section{DEVELOPMENT OF THE HUMAN RESOURCES}

The world is in so-called "intellectual revolution" that requires from every person to actively participate in the economic and social reality and its evolution. This is caused by a fact that development and survival of humans and society are conditioned by the knowledge and creativity of the human resources as developing resources that are a resource without limitations. This tells us that knowledge is a non-dynamic category and resource that is constantly evolving. Modern scientific and technical achievements will be defined in the companies at the speed and efficiency that the level of development of human potentials permits. The human resources development is a continuous process involving the formal education, work experience, relationships with other people and an assessment of personality and abilities, which enables the employee to prepare for future work. [6]

As one group of workers in New York stated in 1829 (A.Toffler, 1983) "With life and freedom, we consider education to be the greatest blessing that has been given to mankind."

The basic component of development the every human being and essential prerequisite of the human activity, both material and spiritual is education. Education is the carrier of every mental and manual work, as well as any spiritual and material creativity. The more education in a society, the less disorder and spontaneity in development, and more rationality and choices. Education - the process of knowledge acquiring is the most often exclusively related to the school education, which is a mistake. It is wider than this process and it lasts throughout lifetime, but it has different forms, content and methods. It is increasingly organized, in addition to the schools, in companies, factories and workplaces as an informal form of education that ensures the professional development of employees. The out-of-school human resource development programs are provided by the management training in companies, mass media, the Internet, scientific and artistic organizations and other organizational forms. In the process of knowledge acquiring, it is necessary to invest, where such investment is considered the most profitable process. [7]

A permanent education system is the basic infrastructure for the growth and development of human resources. It is oriented to the present and future, or to the training of human potentials for contemporary changes and changes in the future. Permanent education is a real social process and a strategy for social development. Under the permanent development of intellectual capital, all organizational activities aimed at completing knowledge, retraining, additional qualifications and other forms of professional development should be understood.

The human resource development goals can be expressed in several points:

- Permanent adjustment of employees' qualifications to the changes in job requirements;

- Motivation of employees;

- Investments in future success with small material investments;

- Company's responsibility to society and the environment;

- Stability of the social status of employyees. In the modern economy on the market, the winning companies are those that learn and truly believe in the idea that people and their knowledge are the greatest and most valuable asset. Modern companies collect information from the environment and turn 
them into knowledge, embed this knowledge into their organizational structure and respond adequately to the issues and problems arising from the environment.

Only "learning organizations" are able to adapt to the changes in their environment, but at the same time initiate changes that give them a competitive advantage. Accordingly, the investments in human resources development, i.e. in their education increases both the value of employees and the value of company as a whole. Development is based on the interaction of individual development objectives and company development goals.

The development of human resources as a factor of the company's success cannot be left up, it must be a targeted and well -thought process, and it is left to the management training in company.

\subsection{Training}

When it comes to the educational function in the company, i.e. development of human resources, it is usually thought of as training. Training is used as a general term related to all organizational activities and programs aimed at raising the level and development of knowledge, skills and abilities of employees. Training in company represents a certain kind of organized permanent education that is related to changes in specific knowledge, skills, attitudes or behavior of employees with the aim of preparing for a better job. This is a company's planned effort to improve the performance of employees at their workplaces. [8]

Investments in the professional development of the human resources in developed parts of the world have become the most profitable investment in the own future and development, and company is a place where they are constantly learning, educating and developing. Many researchers suggest that the competitive companies in the West invest annually between 3 and $5 \%$ of their income to the education and human resources development. Some of these investments may be even greater, in case of strategy change, the introduction of new products, etc. Knowledge is a key factor that makes the difference between the successful and unsuccessful. Whenever it is said that education is expensive, it must be known that a lack of knowledge is much more expensive

The training aims to provide all employyees with the necessary skills to perform their roles in the business process. The state is obliged, through public funding of education, to provide the new participants in the labor market with appropriate qualifications. The companies and individuals are in competence for the continuation of training. The theory of training relies on the learning theories. With this way of acquiring knowledge, the employees of the company can respond correctly and timely to changing the environmental factors that influence the change of company strategies and goals.

The training itself as part of development process in the company is a complex, dynamic, synchronized and coordinated system of interconnected and scientifically determined and professional, predominantly creative and complex activities that take place chronologically at certain stages.

The stages of training as a process in the company are: discovering and determining the training needs, determining the goal, designing the way of realization, realization of the program, evaluating the results, as well as assessing the new values gained by the training. The phases are present in all forms of permanent education and training, and they must be mutually essentially settled, and are carried out according to a predetermined functional order. Only good and professionally designed training will give the good results in development the human resources.

Fitts and Posner (1967) defined a threephase system that explains the process of acquiring skills. The phases occur in the following order: the cognitive phase in 
which an individual understands the nature of the job and how it occurs, associative phase in which an individual connects the input with the corresponding activities without great influence of the external environment, and autonomous phase in which an individual performs tasks independently without the need for cooperation.

The process of organizing the training is a very complex and responsible function of the human resources management or its sector (management training). But the form and method of training realization today is facilitated by development of information technologies, primarily those in education. Internet and new technologies in the field of information and communication are considered as the introductory in the new century, so investments in their development are very costly because they bring positive effects, both in the educational as well as in the economic and social system. The rapid development of information technology led to a change in education, as well as the very way of learning and acquiring a new knowledge. Electronic learning is increasingly complementing the classic forms of training and development, and in many cases their replacement. Thus, different forms of distance education enable the new ways of learning and acquiring knowledge that takes place separately in time and space between the lecturers and program users. The users have the opportunity to choose both timing and content of the program that will be adopted at very low cost. These forms are integral parts of training that take place in companies, making it more quality and efficient in their realization. [9]

Electronic learning has become an indispensable solution that helps companies applying this approach to development through the Information Communication Technology, and take advantage of the opportunities it provides. The strategy of today's educational centers as well as the company should be based on the fact that most of the activities in acquiring knowledge and human re- sources development taking place in a classroom are replaced by the interactive learning in a virtual classroom. The big world companies do $80 \%$ of their development and training through E- education, most often through the Internet (online training). Regardless of company activity, the education becomes the most important investment in future and development of every company which is more and more place for learning and developing.

\section{RESEARCH METHODOLOGY}

Today's scientific and technological progress has brought and imposed the new forms of work, management, new forms of organizational structures and important changes in treatment of developmental factors. Today's economy, besides investment capital and material resources, requires the good and quality human resources in which development should be invested much more.

Research was carried out in the mining companies of different types of activities, as well as with different number and structure of employees.

In this research, there were two hypotheses:

1. The hypothesis that education is not a process that takes place exclusively in the classrooms, but it is a permanent process that takes place, and continuously takes place in various informal forms of education.

2. The hypothesis that the Serbian mining companies increasingly recognize the role and importance of developing their employees as an important development factor.

The aim of the empirical part of the research is to identify the extent to which education and human resources development are represented in the Serbian mining companies, along with all other factors that condition the business in the transition process. 
By the method of the questionnaire, the employees and their managers are examined in certain mining companies in the Republic of Serbia. The questionnaires were sent to the e-mail address of the director of business systems, and the data thus obtained were returned to the database.

The target group of the research is composed of the mining business systems (mining and processing of mineral sourcing) in the Republic of Serbia during the period of conducting this research. For the needs of research, based on the literature in the field of human resources development and the author's experience, a questionnaire with 30 questions was developed (this is not a standardized questionnaire model, but a personal projection).
In addition to the general questions about age, years of service, education and vocational training, the respondents answered the question of whether they are doing the job for which they have been educated and whether they have a sufficient knowledge to carry it out. The rest of the questionnaire relates to their advancement in companies, how often they attend training, what are the links between companies with the educational institutions, how much companies invest in their development, and how much in a new technology. The important question is: Do you want to acquire a new knowledge to keep your company alive?, and many others. $78 \%$ of the planned sample responded to the survey as follows:

The data are processed and sorted by the descriptive statistical methods and the results are the following:

Table 1 Educational structure and strategy of development the mining companies

\begin{tabular}{|l|c|c|c|c|c|c|}
\hline \multirow{2}{*}{$\begin{array}{c}\text { Future company } \\
\text { strategy }\end{array}$} & \multicolumn{6}{|c|}{ Educational structure } \\
\cline { 2 - 7 } & Unskilled & Skilled & $\begin{array}{c}\text { Secondary } \\
\text { education }\end{array}$ & $\begin{array}{c}\text { High } \\
\text { education }\end{array}$ & $\begin{array}{c}\text { Masters } \\
\text { Doctorates }\end{array}$ & Total \\
\hline Closure of companies & 0.9 & 4.5 & 1.2 & 0.4 & - & 7 \\
\hline Training of employees & 2.8 & 14.1 & 3.8 & 1.3 & - & 22 \\
\hline $\begin{array}{l}\text { Process of } \\
\text { reorganization }\end{array}$ & 3.5 & 17.2 & 4.7 & 1.6 & - & 27 \\
\hline $\begin{array}{l}\text { Investing in a new } \\
\text { technology }\end{array}$ & 3.5 & 17.2 & 4.7 & 1.6 & - & 27 \\
\hline $\begin{array}{l}\text { Cooperation of } \\
\text { professional houses }\end{array}$ & 2.2 & 10.8 & 3.0 & 1.0 & - & 17 \\
\hline \multicolumn{1}{|c}{ Total } & 13 & 64 & 17 & 6 & - & 100 \\
\hline
\end{tabular}

Based on these results, the following can be clearly seen: Training of employees as a strategic way of employee development is given a great importance by the employees in the amount of $22 \%$, while the process of reorganization of the mining processes is given as much as $27 \%$, as well as the investments in a new technology also $27 \%$. It is almost a unique goal of all employees to continue working in the mining companies, regardless of difficulties and ownership transformation.
The educational structure of mining employees and future development strategy of the company, based on the obtained frequencies, the results are as follows: $17.2 \%$ of the qualified workforce is in favor of the strategy of reorganization of the process, the same is for investing in a new techno$\operatorname{logy}$, while $14.1 \%$ of the qualified structure employees see training and development of their employees as one of the main strategies for the future development. 
Table 2 Number of employees and their skills

\begin{tabular}{|c|c|c|c|c|}
\hline \multirow{2}{*}{$\begin{array}{c}\text { Employees number } \\
\text { problem }\end{array}$} & \multicolumn{4}{|c|}{ Problem of employees expertise } \\
\cline { 2 - 5 } & $\begin{array}{c}\text { Employment } \\
\text { of new experts }\end{array}$ & $\begin{array}{c}\text { Training of } \\
\text { employees }\end{array}$ & $\begin{array}{c}\text { Other } \\
\text { way }\end{array}$ & $\begin{array}{c}\text { Total } \\
\%\end{array}$ \\
\hline Dismissal \% & 3.3 & 13.13 & 3.13 & 19.6 \\
\hline Reorganization of working places \% & 12 & 47.30 & 11.30 & 70.6 \\
\hline No action \% & 1.7 & 5.65 & 1.57 & 9.8 \\
\hline Total \% & 17 & 67 & 16 & 100 \\
\hline
\end{tabular}

From the networked data, it can be noticed that solving the problem of insufficient professional skills of employees is seen in the development - training as a model of acquiring a new knowledge and developing the new skills, even in $67 \%$ of cases, while a small percentage considers that problem of expertise should be solved by employing the new professionals $17 \%$. However, solving the lack of expertise in the mining company employees see at $47.30 \%$ in the reorganization of workplaces and training of employees in the company.

Since the training itself as a process is a very complex and responsible function of human resources management or its sector, the question arises who will carry this responsible job in the company, or it will be entrusted to the other educational institutions or educational centers.

Table 3 Attitude towards training and realization of training

\begin{tabular}{|c|c|c|c|c|c|}
\hline \multirow{2}{*}{$\begin{array}{c}\text { Attitude towards } \\
\text { training }\end{array}$} & \multicolumn{5}{|c|}{ Time of training organization } \\
\cline { 2 - 6 } & $\begin{array}{c}\text { In the last six } \\
\text { months }\end{array}$ & $\begin{array}{c}\text { In the last } \\
\text { year }\end{array}$ & $\begin{array}{c}\text { 5 years } \\
\text { ago }\end{array}$ & $\begin{array}{c}\mathbf{1 0} \text { years } \\
\text { ago }\end{array}$ & $\begin{array}{c}\text { Total } \\
\%\end{array}$ \\
\hline Yes & 14.0 & 28.0 & 17.5 & 10.5 & 70 \\
\hline No & 6.0 & 12.0 & 7.5 & 4.5 & 30 \\
\hline Total \% & 20 & 40 & 25 & 15 & 100 \\
\hline
\end{tabular}

By analyzing the data the attitude of the employees towards the training and its organization and realization over a certain period in the companies is the following: The attitude of the employees towards the organization and realization of the training is positive at amounts to $70 \%$, with the emphasis that the companies do not have enough professional people to conduct this process, so the specialists must be hired.

Viewed over time, there is a noticeable increase in frequency of the training implementation in the Serbian mining companies, but this is still not satisfactory. The attitude of employees towards training and other factors of company development is analyzed, as shown in the following Table.

Table 4 Training and other factors of company development

\begin{tabular}{|c|c|c|c|c|}
\hline $\begin{array}{c}\text { Attitude towards } \\
\text { training }\end{array}$ & \multicolumn{4}{|c|}{ Development factors } \\
\cline { 2 - 5 } & $\begin{array}{c}\text { Financial } \\
\text { resources }\end{array}$ & $\begin{array}{c}\text { Human } \\
\text { resources }\end{array}$ & $\begin{array}{c}\text { Science and } \\
\text { technology }\end{array}$ & $\begin{array}{c}\text { Total } \\
\%\end{array}$ \\
\hline Yes & 29.4 & 24.5 & 16.1 & 70 \\
\hline No & 12.6 & 10.5 & 6.9 & 30 \\
\hline Total\% & 42 & 35 & 23 & 100 \\
\hline
\end{tabular}


The employees in the Serbian mining companies consider for development factors: the financial resources with $42 \%$ in the overall structure of development factors, human capital and knowledge with $35 \%$, science and technology with $23 \%$. As the science development is component that refers to the human potentials and their knowledge, it can be said that the companies based their development on human resources, 58\% (35\% $+23 \%$ ) and $42 \%$ on financial assets.

\section{CONCLUSION}

The mining production, as much as it prefers to provide the material resources in its operation, it cannot base its further development without intangible resources, i.e. without a new knowledge, innovation, quality, standards, and other values that exclusively relate to the employees, or human resources. Research has shown that it is understood that the quality human resources in the mining companies can enable their explicit growth. If companies have professional and educated human potentials that are ready to innovate and risk in line with market needs, they will succeed in achieving the economic growth and development, not only by the individual functions and organizational parts, but in general. The intellectual capital employed by the employees is a dominant determinant of the value of companies' capital at a given time, which is confirmed by our researches conducted in the Serbian companies that are engaged in the production and processing of ore. Companies that provide a permanent development of their human potential through different forms of training and education create better intellectual capital, have the opportunity for the market expansion, an advantage over the compe-tition, the ability to expand and conquer the new markets, and the opportunity to provide additional capital for their own development. People's proverb says: "If you want to harvest fruit forever then the people have to learn." The same is the case with the companies, those that invest in development of their employees in order to acquire the new knowledge and skills and believe that the knowledge is a key development resource, become the "learning organizations", and provide the better business future. The bases for development in the Serbian mining companies and companies of the developed world is in intellectual capital, but in our practice this indicator of development is not at an enviable level that obliges this problem to become a permanent social concern with much better and more responsible approach.

\section{REFERENCES}

[1] Stewart,T.A (1997): The wealth of Knowledge: Intellectual Capital and the Twenty-First Century Organizational, New York: Doubleda/curreny

[2] Drucker, P. (2005): Management in a New Society, Adizes, Novi Sad (in Serbian)

[3] Torrington, D, Hall,L,Taylor,S. (2004): Management of Human Resources, Data status, Belgrade, 423 (in Serbian)

[4] Noe, R. A. (2010): Employee Training and Development. McGraw-Hill/Irwin, 205-208.

[5] Peters, T: (1996): Successful in Chaos, Grmeč, Belgrade, 1996, 415 (in Serbian)

[6] Radovanović,V. (2009): Management of Human Resources, Faculty of Technical Sciences, Čačak, 65 (in Serbian)

[7] Lee, C. H., \& Bruvold, N. T. (2003): Creating Value for Employees: Investment in Employee Development. The International Journal of Human Resource Management, 14(6), 981-1000.

[8] Goldstein I. L \& Ford K. J. (2002): Training in Organizations - Needs Assessment, Development, and Evaluation, $4^{\text {th }}$ edition, Wadsworth, Belmont. 22.

[9] Milosavljević, G. (2011): Training Design, Faculty of Organizational Sciences, Belgrade (in Serbian) 